\title{
MENYINGKAP FAKTA DAN PERISTIWA DIBALIK TANDA NABI YUNUS
}

\author{
Ditulis oleh Seri Damarwanti, SE, M.Th ${ }^{1}$
}

\begin{abstract}
The books of Old Testament refered to fulfillment the coming of the Messiah in the New Testament. So did the Book of Jonah has written, also the fulfillment of the Messiah in the Gospel. Behind the disagreement in identifying the Book of Jonah as a historical book or parable, an undeniable fact is derived from the words of Jesus Christ, which resulted in the conclusion that "the sign of Jonah" is the only indication of his death and resurrection; equal time : three days and three nights; equality of conditions, both Jonah and Jesus, experienced death for three days and three nights, descended into the abyss and the world of the dead; and on the third day "resurrected" back from the dead, where Jonah was vomited from the belly of the fish and Jesus rose again from His death in the tomb; equality of mission: Jonah and Jesus, aim to preach the message of salvation to all humans.
\end{abstract}

Keywords: Jonah, Jonah's sign, three days and three nights, salvation

\begin{abstract}
Abstrak
Kitab-kitab dalam Perjanjian Lama merujuk pada penggenapan kedatangan dan karya Mesias dalam Perjanjian Baru. Demikian Kitab Yunus ditulis, pun merupakan rujukan dari penggenapan mengenai Mesias di dalam Injil. Dibalik perbantahan dalam mengidentifikasi Kitab Yunus sebagai kitab sejarah atau perumpamaan, fakta yang tidak terbantahkan berasal dari perkataan Yesus Kristus sendiri yang menghasilkan kesimpulan bahwa "tanda Yunus" menjadi petunjuk satu-satunya mengenai kematian dan kebangkitannya; persamaan waktu, yaitu tiga hari dan tiga malam ; persamaan kondisi, yaitu bahwa baik Yunus maupun Yesus sama-sama mengalami kematian selama tiga hari tiga malam, turun ke dalam jurang maut dan dunia orang mati ; dan pada hari yang ketiga "dibangkitkan" kembali dari alam maut, dimana Yunus dimuntahkan dari perut ikan dan Yesus bangkit kembali dari kematianNya dalam kubur ; persamaan misi, yaitu baik Yunus maupun Yesus sama-sama bertujuan untuk memberitakan kabar keselamatan bagi semua manusia.
\end{abstract}

Kata kunci: Yunus, tanda Yunus, tiga hari dan tiga malam, keselamatan.

\footnotetext{
${ }^{1}$ Penulis adalah salah satu pengajar STT Nazarene Indonesia.
} 


\section{Pendahuluan}

Kitab Perjanjian Lama dan Perjanjian Baru merupakan kumpulan buku yang isinya diilhamkan oleh Allah. Kedua kumpulan buku dalam dua perjanjian dipisahkan oleh dua periode yang ditandai dengan kelahiran Yesus Kristus. Perjanjian Lama adalah periode dimana Yesus belum lahir ke dunia, dan Perjanjian Baru adalah periode yang dimulai saat kelahiran Yesus sampai pada Kitab Wahyu yang menubuatkan tentang akhir zaman. Kedua Perjanjian ini tidaklah tidak berhubungan, namun saling berhubungan. Kedua Perjanjian ini berisi tentang segala sesuatu yang tentang Allah dan hubungannya dengan umatNya, dan keduanya saling berhubungan. Inti pesan dalam semua Kitab Perjanjian Lama adalah tentang kedatangan Mesias, yaitu Juruselamat dunia, Yesus Kristus. Jadi semua kisah dan tulisan yang ada di dalam setiap Kitab Perjanjian Lama merupakan nubuat dan rencana Allah tentang akan datangnya Mesias, Juruselamat umat manusia. Sedangkan Perjanjian Baru berisi bagaimana nubuat dan rencana Ilahi itu digenapi, yaitu kedatangan Mesias dalam dunia sampai kepada nubuat akhir zaman yang tercantum dalam Kitab Wahyu.

Setiap Kitab dalam Perjanjian Lama, tidak ada tidak memuat nubuatan dan rencana Allah akan kehadiran Mesias di masa yang akan datang. Mulai dari Kitab Kejadian, permasalahan yang ditimbulkan oleh dosa membawa manusia pada rencana keselamatan Allah. Mesias yang akan datang dimaksudkan untuk menyelesaikan akibat dosa dan menjadi tebusan bagi banyak manusia. Demikian juga dengan Kitab Yunus, masuk dalam rangkaian Kitab yang berbicara tentang Mesias. Secara khusus, paper ini akan membahas bagian Yunus 1:17, "Maka atas penentuan Tuhan datanglah seekor ikan besar yang menelan Yunus; dan Yunus tinggal di dalam perut ikan itu tiga hari tiga malam lamanya". Bagian Firman ini diulangi kembali maksudnya dalam perkataan Yesus di Matius 12:39, Matius 6:4 dan Lukas 11:29 yang tertulis, ”. . angkatan ini adalah angkatan 
yang jahat. Mereka menghendaki suatu tanda, tetapi kepada mereka tidak akan diberikan tanda, selain tanda Nabi Yunus". Hal ini ditegaskan dengan makna yang sama dalam Lukas 11:30, "Sebab seperti Yunus menjadi tanda untuk orang-orang Niniwe, demikianlah Anak Manusia akan menjadi tanda untuk angkatan ini".

\section{Problem Statement}

Dalam paper ini akan dibahas untuk menjelaskan dan membuktikan bagaimana Yunus 1:17 merupakan sebuah gambaran peristiwa untuk peristiwa yang lebih besar yang berhubungan dengan penggenapan nubuatan akan kedatangan dan karya Allah melalui Mesias, Yesus Kristus di dalam Perjanjian Baru. Secara khusus, paper ini akan menjawab pertanyaan: Dalam hal apa Yunus 1:17 memiliki relevansi dan keterkaitan dengan Mesias di Perjanjian Baru?

\section{Kitab Yunus}

Kitab Yunus merupakan salah satu Kitab nabi-nabi kecil dalam Perjanjian Lama. "Pahlawan dalam kitab ini hidup pada abad ke - 8 SM (2 Raja-raja 14:25). Kitab ini adalah sebuah perumpamaan panjang, yang kemungkinan ditulis pada abad ke -6 SM. Kitab ini memaparkan bagaimana Yunus diutus untuk memperingatkan penduduk Niniwe, Ibukota Kerajaan Asyur, atas kejahatannya yang besar serta konsekwensi-konsekwensinya. ${ }^{2}$

Membaca kitab Yunus, pikiran pembaca akan memberikan pendapat seperti yang dikatakan oleh Dr. G. Campbell Morgan bahwa suasana filsafat abad ini telah menciptakan suatu sikap tertentu terhadap Kitab Yunus. Dewasa ini hampir mustahil kita membuka kitab itu dan membaca dari padanya tanpa melihat pikiran orang terpusat pada seekor ikan! Manusia begitu

\footnotetext{
${ }^{2}$ David, L.Baker, Mari Mengenap Perjanjian Lama, (Jakarta: BPK Gunung Mulia), 2011, hal.124.
} 
sibuk mengukur besarnya perut ikan itu, sehingga rupa-rupanya tidak mempunyai waktu untuk menduga dalamnya wahyu Ilahi. ${ }^{3}$

Sebagai sebuah perumpamaan, kitab ini menyiratkan kemurahan Allah yang bersifat universal kepada seluruh manusia, baik orang Yahudi maupun orang bukan Yahudi. Kitab ini merupakan risalah yang menolak nasionalisme sempit, yang dihubungkan dengan Ezra setelah pembuangan. Dalam Matius 12:38-42, dikatakan bahwa ada orang-orang Farisi yang meminta tanda dari Yesus yang hanya memiliki tanda Yunus - perlu adanya pertobatan. Namun tambahan editorial yang tampaknya merupakan nukilan refleksi Kristen mula-mula menganggap Yunus sebagai perlambang kebangkitan Yesus dalam Perjanjian Lama (Matius 12:40).

\section{Siapakah Yunus?}

Arti kata Yunus adalah Merpati. Ia adalah seorang Nabi Ibrani pada masa pemerintahan Yerobeam II, Raja Israel, abad ke-8 SM. Asalnya dari Gat-Hefer, suatu desa suku Zebulon, letaknya disekitar Nazareth. Nama ayahnya ialah Amitai. Ia menubuatkan ekspansi oleh Yerobeam atas wilayah Siria (2 Raja-raja 14:25). Yunus inilah tokoh dari Kitab yang memakai namanya, yakni Nabi ke-5 dari ke-12 Nabi kecil. Kitab Yunus agak berbeda dari Kitab nabi-nabi lainnya karena hampir seluruhnya merupakan cerita dan tidak mengandung ucapan nubuat yang panjang. ${ }^{4}$

\section{Garis Besar Isi Kitab}

Kitab ini terdiri dari 4 bab dimana tiap bab mempunyai pokok bahasan tersendiri. Bab I bercerita tentang Yunus yang diperintahkan Allah ke Niniwe menentang kejahatan, tapi Yunus menolak dan berlayar ke arah yang bertentangan. Badai besar mengamuk dan Yunus dilemparkan

\footnotetext{
${ }^{3}$ Frank M, Boyd, Kitab Nabi-Nabi Kecil, (Malang: Gandum Mas), 2011, hal. 25.

${ }^{4}$ Ensiklopedia Alkitab.
} 
oleh para awak kapal ke laut atas permintaannya sendiri. Lalu nabi itu ditelan oleh seekor ikan raksasa. Bab 2 berisi kalimat doa permohonannya atau mazmur ucapan syukur dari perut ikan itu. Segera sesudah itu Yunus dimutahkan oleh ikan besar itu ke pantai. Bab 3 menceritakan bahwa akhirnya Yunus ke Niniwe. Khotbahnya tentang yang akan datang mendorong penduduk Niniwe untuk bertobat dari hidupnya yang jahat. Bab 4 bercerita tentang Yunus marah-marah karena penduduk Niniwe bertobat sehingga luput dari kemusnahan. Setelah itu, karena kasih sayangnya, Allah menumbuhkan sebuah pohon jarak, dan mengajar Yunus untuk mengasihi semua orang.

\section{Penulis dan Tarikh}

Tidak ada acuan dalam kitab ini tentang siapa penulisnya. Mungkin Yunus sendirilah yang menulisnya, tapi kitab ini tidak pernah memakai kata ganti orang pertama (bertentangan dengan misalnya Hosea 3:1). Boleh jadi tarikhnya sekitar awal abad ke -8 seperti yang tertulis di Yunus 3:3, seolah-olah kota Niniwe tidak ada lagi (kota itu dimusnahkan tahun 612 SM). Jika bukan Yunus penulisnya, tidak seorangpun dapat mengatakan siapakah penulis kitab ini. Tarikhnya mungkin abad ke -8 , tapi boleh jadi tidak lebih dari abad ke -6 .

\section{Pengertian-Pengertian Yang Berbeda}

Sifat kitab ini menimbulkan banyak pertentangan. Ada yang mengatakan kitab itu mitologi,

alegori, tafsiran (Midrasy), perumpamaan dan sejarah. Tapi tudingan bahwa kitab ini mitologi atau alegori sudah ditolak. Para ahli masa kini menalar buku ini terutama sebagai perumpamaan, yang menalarnya sebagai Midrasy.

Nalar yang mengandalkan kitab ini adalah perumpamaan, lebih sederhana dan lebih mungkin. Penganut pandangan ini mengatakan bahwa kitab itu hanyalah suatu cerita mengenai 
perilaku yang dapat dibandingkan dengan cerita Natan kepada Daud (2 Samuel 12:1) atau dengan Perumpamaan Tuhan Yesus tentang Orang Samaria Yang Murah Hati (Lukas 10:30) yang tentu mengajarkan pelajaran yang sama seperti Kitab Yunus. Pendapat yang menalar bahwa Kitab Yunus adalah perumpamaan bukanlah kebijakan yang sahih untuk mengelakkan kepercayaan kepada mukjizat Yunus, yang keluar hidup-hidup dari perut ikan raksasa itu, dalam arti harafiahnya. Ada beberapa perumpamaan seperti itu dalam Alkitab; kritik murahan yang menentang penafsiran ini didasarkan pada ketidaksamaan panjang cerita.

Nalar historis didasarkan pada makna naskah yang begitu gamblang dan bahwa tokoh cerita itu adalah orang tertentu dan nyata ada, yaitu Yunus bin Amitai (padahal tokoh-tokoh dalam perumpamaan-perumpamaan seperti disinggung tidak mempunyai nama). Tradisi Yahudi menalar bahwa kitab ini benar-benar terjadi dalam arti harafiahnya. Dan fakta-fakta Tuhan Yesus juga merujuk ke kitab Yunus (Matius 12 dan Lukas 11) menyiratkan bahwa Yesus juga menalarnya demikian, kendati tidak mutlak. Nalar historis ditentang mengenai beberapa hal terutama mukjizat berkaitan dengan ikan itu, ukuran luas Niniwe dikatakan terlalu besar, pernyataan bahwa Raja dan penduduk kota itu tidak hanya mendengarkan seorang Nabi Ibrani yang asing, tapi juga tanpa ragu dan tanpa syarat bertobat, dan akhirnya, laju pertumbuhan pohon jarak yang tidak alamiah itu.

Tapi mukjizat memang selamanya ajaib, dan kejadian yang serupa dengan ini pernah terjadi pada zaman modern. Pertumbuhan pohon jarak yang begitu cepat bisa saja suatu mukjizat atau dengan cara yang lebih sederhana, orang bisa mempertahankan bahwa Yunus 4:10 tidak dimaksudkan berarti harafiah. Mengenai ukuran Niniwe (Yunus 3:3), mungkin maksud penulis ialah daerah yang lebih luas dari kota itu sendiri. Yang meneguhkan pendapat ini bisa dilihat dalam hal ia menunjuk pada seorang Raja Niniwe (3:6), padahal penulis lain dari Perjanjian Lama berkata bahwa akibat nasib buruk yang menimpa Asyur sebelum Tiglat Pileser III (tahun 745 SM) naik 
tahta, orang Niniwe bersedia mendengarkan nabi yang dinubuatkan malapetakan yang pasti akan menimpa mereka, kecuali mereka bertobat. Agama mereka adalah agama Politeisme, jadi mereka bisa menyingkirkan penghinaan bahkan terhadap Allah asing yang mereka tidak kenal. Dapat dikatakan bahwa tidak satupun keberatan atas nalar historis itu yang tak dapat diatasi. Demikian juga dapat dikatakan tentang nalar perumpamaan.

\section{Tujuan Penulisan Kitab}

Disepakati bahwa kitab Yunus bernafas didaktik. Kalimatnya yang terakhir adalah pertanyaan yang menantang (bandingkan dengan Lukas 10:36). Apakah maksudnya memprotes agama Yudais yang picik dan eksklusif, atau mendorong bangkitnya upaya misi, atau menerangkan ihwal nubuat-nubuat terdahulu mengenai pembinasaan bangsa-bangsa asing yang nampaknya tidak digenapi? Tanpa mengetahui jelas suasana saat penerbitan kitab ini, kita tak dapat menjawab pertanyaan-pertanyaan itu. Namun demikian jawabnya adalah saling terkait. Dan Yunus dengan gamblang menekankan kuasa universal Allah, baik atas orang Yahudi yang durhaka dan segenap Non Yahudi yang kejam.

\section{Susunan Kitab}

Kitab ini umumnya diterima sebagai satu kesatuan kecuali 2:2-9 yang oleh beberapa ahli dianggap sisipan. Tetapi akhir-akhir ini semua cenderung menerima Yunus seutuhnya sebagai asli. Mazmur itu (2:2-9) tidak seaneh seperti dulu dianggap orang. Yunus sudah diselamatkan dari bahaya mati tenggelam, kendati ia belum dibebaskan dari perut ikan itu. Penggunaan Bahasa tradisional kelautan untuk menggambarkan maut sangat cocok. Makna harfiah istilah-istilah itu mendasari rujukan dalam Perjanjian Baru perihal tafsir dan maknanya. 


\section{Tentang Niniwe}

Kota ini mempunyai luas yang luar biasa. 3 hari perjalanan luasnya. Besaran ini bisa dipandang berdasarkan besarnya tugas dan lamanya tinggal menetap daripada dengan keliling atau diameter sebenarnya kota tersebut. Namun Wisemann menuliskan bahwa menurut penggalian A.H Layard di lokasi Niniwe pada tahun 1843 menyatakan daerah yang jauh lebih kecil. Perhatian dilakukan kepada lingkaran tembok-tembok yang telah diperbesar oleh Sanherib dari 9.300 kubik ke 12.515, yang memberikan jarak sekitar 7,5 mil. Populasi penduduknya sekitar 12.000 orang. Kota ini didirikan oleh Nimrod (Kejadian 10:11) dan merupakan ibukota Asyur.

Kota ini dinamai kota pertumpahan darah, besar, kaya, kuat perdagannya rame, penduduknya banyak (Nahum 3). Karakter penduduk kota ini: jahat (Yunus 1:2), penyembah berhala (Nahum 1:14), penuh keramaian tapi penduduknya santai (Zef 2:15), penuh dengan dusta dan perampasan (Nahum 3:1), penuh persundalan (Nahum 3:4). Kejatuhannya sudah dinubuatkan oleh Nahum dan Zefanya (612 SM), akibat air sungai yang bendungannya bobol (Nahum 2:6-8).

\section{Pembahasan Tentang Tanda Nabi Yunus}

Seperti yang telah disinggung dalam bagian terdahulu, bagian yang paling penting dalam paper ini adalah membahas bagaimana bagian Yunus 1:17 (Maka atas penentuan Tuhan datanglah seekor ikan besar yang menelan Yunus; dan Yunus tinggal di dalam perut ikan itu tiga hari tiga malam lamanya), digenapi dalam kehidupan Mesias dalam Perjanjian Baru di Matius 12:39, Matius 6:4 dan Lukas 11:29 yang tertulis, ”. . angkatan ini adalah angkatan yang jahat. Mereka menghendaki suatu tanda, tetapi kepada mereka tidak akan diberikan tanda, selain tanda Nabi Yunus". Hal ini ditegaskan dengan makna yang sama dalam Lukas 11:30, "Sebab seperti Yunus menjadi tanda untuk orang-orang Niniwe, demikianlah Anak Manusia akan menjadi tanda untuk angkatan ini". 


\section{Perspektif Yesus Dalam Perjanjian Baru}

Dalam pengajarannya, sampailah Yesus pada point bahwa Ia harus mengatakan secara tersirat bahwa Anak Manusia akan mati sebagai tebusan bagi banyak orang, namun akan dibangkitkan kembali, mengalahkan maut pada hari yang ketiga. Pengajaran yang sebenarnya diprioritaskan kepada para murid, tidak dapat dihindari didengarkan juga oleh para ahli Taurat dan orang-prang Farisi. Point mengenai ini sungguh memancing rasa ingin tahu mereka. Hal ini dengan jelas dituliskan dalam Injil Matius berikut ini:

Tanda Yunus (Matius 12:38-42)

(38) Pada waktu itu berkatalah beberapa ahli Taurat dan orang Farisi kepada Yesus: "Guru, kami ingin melihat suatu tanda dari padaMu". (39) Tetapi jawabnya kepada mereka: "Angkatan yang jahat dan tidak setia ini menuntut suatu tanda. Tetapi kepada mereka tidak akan diberikan tanda selain tanda nabi Yunus. (40) Sebab seperti Yunus tinggal di dalam perut ikan tiga hari tiga malam, demikian juga Anak Manusia akan tinggal dalam Rahim bumi tiga hari tiga malam. (41) Pada waktu penghakiman orang-orang Niniwe akan bangkit bersama angkatan ini dan menghukumnya juga. Sebab orang-orang Niniwe itu bertobat setelah mendengar pemberitaan Yunus, dan sesungguhnya yang ada di sini lebih daripada Yunus! (42) Pada waktu penghakiman, ratu dari Selatan itu akan bangkit bersama dengan angkatan ini dan ia akan menghukumnya juga. Sebab ratu ini datang dari ujung bumi untuk mendengar hikmat Salomo, dan sesungguhnya yang ada di sini lebih daripada Salomo!"

Tanda Yunus (Lukas 11:29-32)

(29) Ketika orang banyak mengerumuniNya, berkatalah Yesus: "Angkatan ini adalah angkatan yang jahat. Mereka menghendaki suatu tanda, tetapi kepada mereka tidak akan diberikan tanda selain tanda nabi Yunus. (30) Sebab seperti Yunus menjadi tanda untuk orang-orang Niniwe, demikian pulalah Anak Manusia akan menjadi tanda untuk angkatan ini. (31) Pada waktu penghakiman, ratu dari Selatan itu akan bangkit bersama orang dari angkatan ini dan ia akan menghukum mereka. Sebab ratu ini datang dari ujung bumi untuk mendengarkan hikmat Salomo, dan sesungguhnya yang ada di sini lebih daripada Salomo! (32) Pada waktu penghakiman, orang-orang Niniwe akan bangkit bersama-sama angkatan ini dan mereka akan menghukumnya. Sebab orang-orang Niniwe itu bertobat waktu mereka mendengarkan pemberitaan Yunus, dan sesungguhnya yang ada di sini lebih daripada Yunus!" 
Seorang "Raja" dalam perspektif Bangsa Yahudi adalah ia yang datang dari keturunan raja dan memiliki darah kerajaan. Jadi ketika Yesus menyatakan diriNya sebagai Raja orang Yahudi, hal ini menjadi sebuah perdebatan dan pertentangan di kalangan mereka. Apalagi bila dikaitkan dengan statusNya sebagai Mesias dan Juruselamat. Orang Yahudi dalam tradisi dan pengetahuan agama yang diwariskan secara turun temurun memiliki sudut pandang bahwa Mesias haruslah datang dengan segala kemegahanNya, dilahirkan dari keturunan biologis seorang Raja, hidup dalam keagungan dunia. Jadi ketika Yesus menyatakan bahwa Ialah Raja dan Mesias yang dijanjikan itu, dan dielu-elukan dalam sambutan Hosana, diberkatilah Ia yang datang dalam Nama Tuhan, hal itu seolah-olah adalah sebuah kebohongan besar. Orang-orang Farisi dan Ahli Taurat merasa curiga bahwa Yesus memiliki maksud tidak baik dengan pengakuannya itu sehingga ketika Yesus mengaku bahwa Ialah yang dimaksud para Nabi dalam Perjanjian Lama, yang selalu dinubuatkan kedatangannya, dipandang dengan sebelah mata dan penuh tanda tanya oleh mereka yang tidak mempercayainya.

Dalam pikiran Ahli Taurat dan Orang Farisi, Yesus sudah mengajarkan sesuatu yang sesat. Apalagi bila melihat Yesus banyak mengutip Taurat sebagai ajaranNya, namun di sisi lain mengkritik dengan keras perilaku orang Farisi dan Ahli Taurat yang dalam semua hal justru hidupnya bertentangan dengan Taurat. Kecurigaan berubah menjadi kebencian. Ditambah dengan ketidakpercayaan dan prasangka bahwa Yesus tidak lebih dari seorang pembohong dan penipu yang memutarbalikkan ajaran Taurat yang selama ini mereka agungkan. Atas dasar inilah maka para Ahli Taurat dan Orang Farisi selalu mengikuti kemanapun Yesus pergi dan mengajar orang banyak. Mereka mengikuti Dia dalam rombongan yang sama dengan para murid dan orang-orang lain, namun mendengarkan untuk tujuan yang berbeda. Bilamana para murid dan sebagian besar orang mengikuti Yesus dan mendengarkan pengajaranNya didasarkan atas keingintahuan dan rasa 
haus akan kebenaran, orang Farisi dan Ahli Taurat mendengarkan dan mengikuti Yesus untuk mencari kesempatan menjatuhkan Dia, mencari kesalahanNya supaya dapat menjadi alasan untuk menangkap dan membinasakanNya.

Dan yang terpenting dari itu semua adalah, Mesias yang akan datang, dalam perspektif orang agama Yahudi adalah mereka yang datang sebagai utusan Allah, bukan Allah itu sendiri. Datang dari surga dan karena Ia utusan Allah, maka Mesias haruslah dapat melakukan segala mukjizat dan tanda-tanda supranatural yang spektakuler yang sifatnya Ilahi dan tidak dapat dilakukan oleh orang lain. Permintaan mereka agar Yesus memberikan sebuah tanda, maksudnya adalah bahwa, mereka menginginkan suatu kepastian yang tidak diragukan yang dapat membuktikan bahwa Yesus adalah Mesias dan Raja atas mereka. Sosok yang selama ini menjadi obyek nubuatan dalam Kitab Nabi-Nabi Perjanjian Lama. Bilamana Yesus dapat melakukan mukjizat yang menurut mereka spektakuler dan bersifat Ilahi, atau menunjukkan bukti-bukti lain yang membuktikan bahwa Ialah Mesias yang dimaksud itu, maka mereka akan puas. Apakah mereka akan mempercayaiNya? Sepertinya TIDAK. Karena sejak awal mereka sudah terpenjara pikiran dan hatinya. Mereka menanyakan itu hanya untuk menjebak Yesus dalam perkataanNya sendiri dan mencari kesempatan baik untuk menjatuhkanNya.

Inilah yang membuat Yesus tidak memberikan tanda papaun kepada mereka, sekalipun Ia mampu dan sanggup. Karena tujuan mereka sudah jauh dari harapan Yesus. "Tanda" dalam Bahasa Yunani = shmeion semeion, yang mengandung arti: a sign, mark, tokenthat by which a person or a thing is distinguished from others and is known; a sign, prodigy, portent, i.e. an unusual occurrence, transcending the common course of nature; of signs portending remarkable events soon to happen of miracles and wonders by which God authenticates the men sent by him, or by which men prove that the cause they are pleading is God's. An indication, especially 
ceremonially or supernaturally: KJV -- miracle, sign, token, wonder. Yesus mengatakan bahwa mereka tidak akan mendapatkan danmelihat tanda apapun selalin dari "tanda Nabi Yunus".

Tanda Nabi Yunus yang dimaksud oleh Yesus, mengacu pada Matius 12:40, “. . Sebab seperti Yunus tinggal di dalam perut ikan tiga hari tiga malam, demikian juga Anak Manusia akan tinggal dalam Rahim bumi tiga hari tiga malam”. Yesus berbicara mengenai sebuah tanda dimana Ia menarik keterkaitan antara kisah Yunus bahwa: sebagaimana Yunus berada tiga hari dan tiga malam dalam perut ikan, makan Anak Manusia akan tinggal dalam Rahim bumi selama tiga hari tiga malam. Ada dua persamaan dalam bagian Yunus 7:12 dengan Matius 12:40, yaitu: (1) persamaan waktu. Yunus dan Yesus sama-sama berada dalam perut bumi selama tiga hari dan tiga malam; (2) sama-sama berada di perut bumi bagian dalam. Yunus berada di dalam perut ikan, di dasar lautan yang gelap, sedangkan Yesus masuk ke Rahim bumi. Mengenai persamaan jangka waktu dan tempat, dapat dijelaskan bahwa itu bukan hanya mengacu pada sebuah tempat yang sama-sama di dasar bumi yang gelap, namun lebih dari itu, Rahim bumi mengacu pada sebuah makna yang merujuk pada suatu tempat dalam dunia yang gelap, kesendirian, jauh dari kehidupan, dekat dengan maut dan kematian. Konotasi bahwa kegepalan dalam Rahim bumi menarik pikiran kita bahwa itu merupakan rujukan tentang sebuah tempat di alam maut yang gelap, terpisah dari hadirat Allah, yaitu kematian dan kubur.

Artinya, baik Yunus maupun Yesus, mengalami kematian dan tinggal dalam alam maut selama tiga hari dan tiga malam. Yunus mengalami kematian selama ia dalam perut ikan di dasar laut yang paling dalam. Walaupun banyak peristiwa yang menunjukkan di masa sekarang bahwa manusia dapat tinggal selama berhari-hari dalam perut ikan dan keluar, selamat dalam keadaan hidup, namun makna yang terkandung dalam kisah Yunus ini selain bahwa Yunus mengalami kematian jasmani, ia juga mengalami kematian rohani. Karena setelah peristiwa dalam perut ikan, 
Yunus dapat memahami kasih dan rencana Allah bagi bangsa-bangsa lain juga. Ego Yunus mati. Ia tidak lagi mementingkan diri sendiri dan dengan eksklusif menganggap bahwa keselamatan yang dari Allah hanya berlaku bagi Bangsa Yahudi. Setelah peristiwa dari dalam perut ikan, Yunus menjadi pribadi yang baru yang dapat mengalahkan dirinya sendiri dan menyamakan persepsinya tentang keselamatan yang dari Allah sesuai dengan sudut pandang Ilahi. Ia siap pergi ke Niniwe dan oleh peringatan yang diberikannya melalui wahyu Allah, orang-orang Niniwe diselamatkan.

Sedangkan bagi Yesus, hal ini membawa pemikiran kita pada tiga hari kematianNya sejak dari kayub salib, dikuburkan di Golgota dan dibangkitkan kembali pada hari ketiga. Tiga hari Yesus berada dalam alam maut dan mengalami keterpisahan dari Allah. Namun di hari yang ketiga Ia menunjukkan kuasaNya dan kebangkitanNya dari dunia orang mati. Sama seperti Yunus sudah masuk dalam perut bumi di dasar samudra selama tiga hari dan tiga malam, Yesuspun masuk dalam alam dasar bumi, alam kubur, selama tiga hari dan tiga malam. Hal ini memang akan dialami Yesus. Kisah Yunus menjadi sebuah pertanda yang akurat mengenai waktu dan tempat yang akan dialami Yesus dalam mewujudkan kehendak Allah atas diriNya, yaitu keselamatan umat manusia.

Ada perbedaan dalam tulisan Matius dan Lukas mengenai Tanda Yunus, yaitu bahwa di Lukas tidak dituliskan mengenai lamanya waktu dan tempat tentang tanda itu. Namun ini bukanlah perbedaan yang penting, dalam arti bahwa, Tanda Yunus yang menjadi judul perikop ini mengacu sudah tentu mengacu pada sebuah peristiwa yang sama, yaitu peristiwa tiga hari dan tiga malam berada di dalam perut ikan. Dasar bumi yang paling dalam dan pekat. Kematian yang sebenarnya. Keterpisahan dari Allah. Perbedaan ini tidak membuat makna dari bagian dan tujuan Firman ini menjadi berubah atau kehilangan maknanya. Makna dan artinya sama. Pesan yang ingin disampaikan sama. Hal lain yang menjadi persamaan danpatut untuk dilihat adalah bagian yang menunjukkan bahwa “. . . sesungguhnya yang yang ada di sini lebih dari Salomo dan Yunus". 
"Lebih dari" dalam Bahasa Yunani menunjukkan atau pleon genetif onov nominatif jamak pleionev atau pleiouv (komperatif (perbandingan) dari poluv) lebih (banyak) daripada (tentang perbandingan); pollw $\boldsymbol{p}$. jauh lebih banyak.

Dalam bagian ini Yesus menyatakan: "Pada waktu penghakiman orang-orang Niniwe akan bangkit bersama angkatan ini dan menghukumnya juga. Sebab orang-orang Niniwe itu bertobat setelah mendengar pemberitaan Yunus, dan sesungguhnya yang ada di sini lebih daripada Yunus!" (Matius 12:41) dan pesan yang sama dikatakan juga dalam Lukas 11:32, "Pada waktu penghakiman, orang-orang Niniwe akan bangkit bersama-sama angkatan ini dan mereka akan menghukumnya. Sebab orang-orang Niniwe itu bertobat waktu mereka mendengarkan pemberitaan Yunus, dan sesungguhnya yang ada di sini lebih daripada Yunus!"

Bagian ini berbicara mengenai Niniwe yang akhirnya bertobat setelah mendengar pemberitaan Yunus. Niniwe yang oleh karena dosa dan kekejian yang dilakukannya, seharusnya layak dan pantas mendapatkan hukuman Allah. Pada bagian awal Allah menyatakan kepada Yunus bahwa oleh karena perbuatan Niniwe jahat di mata Tuhan, maka mereka akan mendapatkan penghukuman Allah, namun penghukuman itu akan dibatalkan apabila Yunus ke sana dan memerintahkan supaya orang Niniwe bertobat dan berbalik kepada Allah. Walaupun pada awalnya Yunus menolak, namun akhirnya ia melakukan apa yang diperintahkan Allah. Sesuai dengan yang diharapkan, setelah mendengar perkataan Allah melalui Yunus, orang-orang Niniwe bertobat dan berbalik kepada Allah. Penyesalan mereka membuat Allah memberikan pengampunan dan pembatalan hukuman. Yunus yang dengan segala kelebihan dan kekurangannya sebagai manusia saja dapat dipakai Allah untuk membuat orang-orang Niniwe bertobat, apalagi Yesus. Yesus pada masanya, sebenarnya adalah lebih daripada Yunus. Baik dari sisi identitas (Ia adalah Anak Allah), baik dari sisi kemampuan (Ia memiliki kuasa), dan dari sisi tujuan (Ia adalah Mesias yang datang 
dengan misi khusus). Artinya, Yesus lebih dari Yunus dalam semua hal. Mengapa orang-orang tidak bertobat? Atau dengan kata lain, melihat dan mempertimbangkan siapa yang berbicara, bukankah sudah seharusnya Orang Yahudi dan Ahli Taurat, semua orang pada masa itu yang mendengarkan pengajaran Yesus, BERTOBAT dan berbalik kepada Allah? Atau, eksistensi Yesus sudah seharusnya menjadi dasar orang untuk bertobat. Dia sosok yang memiliki kapabilitas untuk membuat semua orang seharusnya bertobat dari segala dosanya. Berbalik kepada Allah dan menerima keselamatan untuk hidup kekal!

Dalam bagian yang lain Yesus juga menyatakan di dalam Matius 12:42, "Pada waktu penghakiman, ratu dari Selatan itu akan bangkit bersama dengan angkatan ini dan ia akan menghukumnya juga. Sebab ratu ini datang dari ujung bumi untuk mendengar hikmat Salomo, dan sesungguhnya yang ada di sini lebih daripada Salomo!" Dan hal yang sama dituliskan dalam Lukas 11:31, "Pada waktu penghakiman, ratu dari Selatan itu akan bangkit bersama orang dari angkatan ini dan ia akan menghukum mereka. Sebab ratu ini datang dari ujung bumi untuk mendengarkan hikmat Salomo, dan sesungguhnya yang ada di sini lebih daripada Salomo!"

Dalam teks ini sekali lagi Yesus mengulang point sebelumnya mengenai kapabilitasnya sebagai pembawa berita keselamatan dari Allah. Bagian ini secara langsung Yesus berbicara mengenai angkatan yang ada saat itu, yaitu bahwa di masa yang akan datang, mereka semua akan dibangkitkan dan bersiap menuju pada penghakiman Allah. Orang-orang yang memang selayaknya mendapatkan hukuman akan menerimanya tanpa penangguhan. Yesus tidak berbicara tentang Niniwe, namun berfokus pada orang-orang yang ada di situ, yang mendengarkan pengajarannya, khususnya para Ahli Taurat dan Orang Farisi. Ratu dari Selatan mengejar Salomo untuk mendengarkan hikmatnya. Yesus, yang berbicara dan mengajar pada saat itu, menyatakan bahwa dalam hal hikmat, Ia melebihi Salomo. Bilamana Salomo saja dicari dan didengarkan 
karena hikmatnya, apalagi dengan Yesus. Yesus lebih berhikmat dari Salomo. Ialah Allah, Raja dari segala hikmat. Jadi sudah sepatutnya perkataan Yesus didengarkan karena Allah sendirilah yang berkata-kata melalui manusia Yesus Kristus.

Dua ayat yang berbicara mengenai kelebihan Yesus dibandingkan dengan Salomo dan Yunus bermaksud membuka mata dan pikiran pendengar saat itu bahwa Yesus memperkenalkan eksistensi dirinya yang sebenarnya. Orang - orang perlu tahu identitasnya yang sebenarnya. Anak Manusia yang adalah Anak Allah, Mesias yang dijanjikan Allah, yang kedatangannya sudah dinubuatkan oleh para nabi terdahulu. Selain itu, Yesus menegaskan tentang inti iman yang paling penting: kematian dan kebangkitannya. Kematian dan Kebangkitannya dari kematian dan kemenangannya atas maut merupakan inti Iman Kristen yang diberitakan. Ia memberikan tanda Yunus sebagai petunjuk tentang bagaimana karya keselamatan itu akan datang dan diterima manusia. Tidak ada tanda lain, tidak ada pesan lain yang lebih penting dari pesan mengenai kematian dan kebangkitannya. Bagian ini juga menegaskan secara tertulis bagaimana nubuat mengenai Mesias yang diberitakan oleh para Nabi terdahulu akan digenapi dengan kedatangan Yesus. Hal ini akan dijelaskan dengan lebih lengkap dalam bagian berikut ini:

\section{Menarik Mundur Yunus 1:17}

Yunus 1:17 merupakan inti ayat yang menjadi fokus pembahasan paper ini karena pada bagian ini, melalui pengalaman Yunus di dalam perut ikan, terhubung dan terkoneksi dengan bagian lain dalam Perjanjian Baru, yang merupakan penggenapan dari tanda Yunus. Ada relevansi yang sangat signifikan dan akurat mengenai tanda Yunus di Yunus 1:17 dengan Matius 12:40 dan Lukas 11:29. Yunus 1:17 tertulis, "Maka atas penentuan Tuhan datanglah seekor ikan besar yang menelan Yunus; dan Yunus tinggal di dalam perut ikan itu tiga hari tiga malam lamanya". 
“Atas penentuan Tuhan”. Dalam Bahasa Ibrani = hnm manah; yang artinya to count, reckon, number, assign, tell, appoint, prepare; dan dalam arti bebas Bahasa Indonesia mengandung makna perhitungan / penetapan / takdir / kehendak Allah. Artinya bahwa apa yang dialami Yunus, bagian tergelap dan terburuk dalam pengalamannya di kitab ini, terjadi atas penentuan Tuhan. Ada dalam kehendak, control dan pengendalian Tuhan. Bukan kebetulan saja Yunus ada dalam perut ikan yang besar. Pengendalian tangan Tuhan terjadi ketika setelah ia menolak pergi ke Niniwe, Yunus melarikan diri dengan kapal ke Tarsis. Adanya badai dan gelombang yang dahsyat, menarik dan membuang undi, Yunus masuk ke dalam lautan yang bergelora kemudian ditelan oleh ikan besar, tinggal dalam perut ikan selama tiga hari tiga malam, mengalami kematian dan turun dalam bagian bumi yang paling bawah, sampai akhirnya ia dimuntahkan kembali dalam keadaan selamat, . . . semuanya itu terjadi atas kehendak, prakarsa, ide, pengendalian dan penentuan Tuhan. Tuhan adalah sosok yang berada di belakang apa yang Yunus alami. Semua terjadi pada Yunus atas sepengetahuan Tuhan.

"Ikan besar". Dalam Bahasa Ibrani berarti gadowl; yang artinya great, high, greater, loud, greatest, elde, great man, mighty, eldest; dan diterjemahkan dalam Bahasa Indonesia dengan makna sangat besar, sangat nyaring, sangat hebat. Banyak orang mengiran ikan besar ini adalah Paus karena pada zaman sekarangpun ada peristiwa-peristiwa luar biasa dimana orang tertelah masuk dalam perut ikan selama 2-3 hari dan dapat diselamatkan dalam keadaan hidup. Namun Alkitab tidak menuliskan secara jelas jenis ikan ini. Hanya dikatakan bahwa ada "ikan besar". Mungkin nama dan jenis ikan itu tidaklah begitu penting karena bukan itu inti beritanya.

Namun ada ikan besar yang rongga perutnya dapat menampung Yunus masuk ke dalamnya dan tinggal selama tiga hari tiga malam itulah yang penting. Membayangkan bahwa Yunus tertelah dan ada dalam ikan itu selama beberapa hari, tanpa makan dan minum. Ruangan yang basah, gelap 
dan bau, dan berada jauh di dalam dasar lautan. Tempat ini mengisyaratkan keterpisahan dari dunia dan hadirat Allah. Kegelapan dan tiadanya jalan keluar merupakan bentuk dari kesendirian dan kehilangan persekutuan dengan Allah. Kelihatannya Yunus ada dalam dunia maut dan kematian. Mazmur yang dilantunkannya menunjukkan bahwa waktu ini menjadi waktu dimana Yunus merenungkan kebesaran Allah dan berbalik menjadi taat kepada Allah. Selama tiga hari dan tiga malam Yunus mengalami pertemuan dengan maut dan kematian, berada di bagian bumi yang paling dalam, terpisah dengan hadirat Allah. Namun ia atas perkenan Allah dihidupkan kembali dan keluar dengan selamat dari dalam perut ikan di dasar lautan. Bagian ini secara langsung menjadi isyarat atau tanda bagaimana Kristus akan mati dan dibangkitkan pada hari ketiga. Pertanda ini digenapi di dalam Kisah Kematian dan kebangkitan Yesus di dalam Injil Matius, Markus, Lukas dan Yohanes.

"Menelan”. Dalam Bahasa Ibrani berarti bala; yang mengandung makna to make away with (specifically by swallowing); generally, to destroy: KJV -- cover, destroy, devour, eat up, be at end, spend up, swallow down (up) ; yang dalam Bahasa Indonesia kurang lebih artinya menelan, memakan, mengacaukan, membinasakan, memusnahkan, menghancurkan.Dalam penafsiran bebas dapat dituliskan bahwa Ikan besar yang menelan Yunus itu dimaksudkan Allah tidak hanya untuk menelan Yunus masuk dalam perutnya, namun secara simbolik dipakai Allah untuk membinasakan sifat kedagingan Yunus yang tidak mau tunduk kepada Allah. Berarti yang dimusnahkan bukan tubuh Yunus, namun sifatnya yang tidak mau tunduk pada otoritas Allah.

Pertanyaan yang paling penting yang relevan dengan perkataan Yesus mengenai "tanda Yunus" adalah: matikah Yunus dalam perut ikan? Hal ini perlu diketahui karena apabila Yesus mengatakan bahwa "tanda Yunus" akan menjadi satu-satunya petunjuk mengenai Yesus, maka artinya, Yunus juga "harus mati” untuk menunjukkan bahwa kedua peristiwa dalam Kitab Yunus 
dan Perjanjian Baru itu merupakan petunjuk yang menggenapi. Menurut Frank M Boyd, Petunjuk atas jawaban ini ada di ayat 2:

"dari tengah-tengah dunia orang mati (Ibrani = Sheol) aku berteriak". Kata Ibrani untuk "Sheol" dipakai berulang-ulang dalam Perjanjian Lama untuk tempat roh-roh orang yang sudah meninggal; dunia di bawah, kemana jiwa orang benar maupun orang fasik pergi sesudah mati. Untuk sementara waktu jiwanya pergi ke Sheol dan tubuhnya terbaring dalam perut ikan tiga hari tiga malam. Rupanya tafsiran ini cocok, meskipun kita tidak menyangkal bahwa kemungkinan Allah dapat memelihara dia sehingga dia tetap hidup di perut ikan itu. Jikalau Yunus benar-benar mati, maka lambing dalam Matius 12:40 mengenai kebangkitan akan lebih kuat lagi.

Pernyataan bahwa Yunus mati selama tiga hari dan bukan dalam keadaan hidup selama di dalam perut ikan besar itu didukung oleh Kramer yang berpendapat bahwa kata: ikan itu "menelan" Yunus, yang dalam Bahasa Ibrani = bala, sebuah ungkapan yang sangat sering dituliskan dalam Perjanjian Lama, menggambarkan suatu keadaan yang sangat membahayakan, sampai membawa bahaya maut (bandingkan dengan Mazmur 69:16, 106:17, Keluaran 5:12 dan Yeremia 51:34). Memang ada penafsir yang menyatakan bahwa Tuhan mengirimkan ikan besar untuk menyelamatkan Yunus dari kebinasaan, namun sebenarnya yang terjadi justru sebaliknya. Justru ikan besar itu datang dan menelan Yunus untuk membinasakan dia sehingga ketika Yunus ada dalam perut ikan, ia berada dalam bahaya maut yang sangat besar. Ikan itu menjadi lambing ular naga yang hidup di perairan bawah bumi (bandingkan dengan Yeremia 51:34). Hal ini dikuatkan dengan ucapan Yunus di ayat 2:2b, "dari tengah-tengah dunia orang mati aku berteriak" sangat cocok dengan keadaan ini. Ikan itu mnjadi lambing dunia maut bagi Yunus. ${ }^{5}$

${ }^{55}$ A. Th.Kramer, Tafsiran Alkitab Kitab Yunus, (Jakarta : BPK Gunung Mulia), 1998, hal 30-31 


\section{Perbedaan Dan Persamaan Antara Yunus Dan Yesus}

Pada intinya, kehidupan Yunus merupakan nubuat bagi kehidupan Yesus kelak. Namun walaupun dalam pembahasan di atas sudah diuraikan mengenai persamaan Yunus dengan Yesus, yaitu bahwa: (1) Yunus dan Yesus sama-sama diutus Allah untuk menunjukkan jalan kebenaran dan keselamatan bagi manusia; (2) Yunus dan Yesus sama-sama pernah berada dalam lembah maut dan kegelapan kematian, Yunus di dalam perut ikan, dan Yesus di kayu salib smpai Ia dikuburkan; (3) Yunus dan Yesus sama-sama menyuarakan suara Allah untuk membawa manusia bertobat dan diselamatkan.

Di samping persamaan-persamaan tersebut, terdapat beberapa perbedaan antara Yunus dan Yusuf, yaitu: (1) Yunus merupakan nabi Allah yang diutus untuk memberitakan perkataan Allah kepada orang-orang Niniwe, sedangkan Yesus adalah Anak Manusia, Ia adalah Anak Allah yang memiliki kuasa dan otoritas yang lebih tinggi dari Yunus, lebih berhikmat dari Salomo; (2) Pemberitaan Yunus tentang Firman Allah kepada orang-orang Niniwe langsung membawa dampak pertobatan saat itu juga, sedangkan pemberitaan Yesus mengenai diriNya sendiri dan karya keselamatan Allah berproses dan memakan waktu yang lama; (2) Ernest Baturi menyatakan satu perbedaan yang menyolok dari Yunus dan Yesus, yaitu bahwa Yunus tidak seperti Kristus ketika ia melarikan diri dari pekerjaan Allah, sedangkan Yesus sejak awal menerima tugas misi Allah untuk keselamatan manusia. ${ }^{6}$

\section{Relevansi dan Interkoneksi antara Perjanjian Lama dan Perjanjian Baru}

Jadi, setelah meneliti bagian Firman Tuhan di atas, dapat disimpulkan bahwa ada koneksi dan relasi antara Kisah Yunus, khususya pada bagian Yunus 1:17 dengan Matius 12:38-42 dan

\footnotetext{
${ }^{6}$ Sani Baturi, Ernest dan Freda Maxwell, Melihat Ke Dalam Perjanjian Lama, (Jakarta: kalam Hidup), 1998, hal.274-277.
} 
Lukas 11:29-32. Kisah Yunus dalam perut ikan di ayat 1:17 menjadi bagian yang dipakai oleh Yesus dalam memberikan petunjuk kepada para murid, para Orang Farisi dan Ahli-ahli Taurat untuk memberitahu mereka mengenai bagaimana Ia akan mati dan turun dalam alam maut selama 3 hari dan dibangkitkan kembali pada hari yang ketiga. Dan ternyata petunjuk ini dengan tepat digenapi dalam kisah kematian dan kebangkitan Yesus Kristus di dalam Injil, khususnya Matius 27-28, Markus 15-16, Lukas 23-24, Yohanes 19-20. Semua berbicara mengenai kematian dan kebangkitan Yesus dan bagaimana ia dibangkitkan pada hari yang ketiga setelah kematiannya. Hal ini ditegaskan kembali di Kisah Para rasul 10:40, 27:19 dan ditegaskan kembali oleh Rasul Paulus di 1 Korintus 15:4 bahwa Yesus mati, dikuburkan dan dibangkitkan kembali pada hari yang ketiga sesuai dengan apa yang tertulis dalam Kitab Suci (perkataan nabi di Perjanjian Lama).

\section{Kesimpulan}

Menjawab Problem Statement, yaitu bagaimana Yunus 1:17 dapat menjadi gambaran untuk peristiwa yang lebih besar yang berhubungan dengan penggenapan nubuatan akan kedatangan dan karya Allah melalui Mesias, Yesus Kristus di dalam Perjanjian Baru? Atau dalam hal apa Yunus 1:17 memiliki relevansi dan keterkaitan dengan Mesias di Perjanjian Baru? Maka berdasarkan penelitian yang atas berbagai sumber, dapat dijawab sebagai berikut: Yunus 1:17 memiliki keterkaitan dengan Perjanjian Baru. Kisah Yunus dalam perut ikan merupakan petunjuk akan sebuah peristiwa besar di masa yang akan datang, yaitu kematian dan kebangkitan Kristus.

Fakta ini didasarkan pada: (1) Perkataan Yesus sendiri bahwa "tanda Yunus" menjadi petunjuk satu-satunya mengenai kematian dan kebangkitannya; (2) persamaan waktu, yaitu tiga hari dan tiga malam; (3) persamaan kondisi, yaitu bahwa baik Yunus maupun Yesus sama-sama mengalami kematian selama tiga hari tiga malam, turun ke dalam jurang maut dan dunia orang 
mati; (4) dan pada hari yang ketiga “dibangkitkan” kembali dari alam maut, dimana Yunus dimuntahkan dari perut ikan dan Yesus bangkit kembali dari kematianNya dalam kubur; (5) persamaan misi, yaitu baik Yunus maupun Yesus sama-sama bertujuan untuk memberitakan kabar keselamatan bagi semua manusia. Yunus kepada penduduk Niniwe yang bukan orang Yahudi saja, dan Yesus juga kepada semua umat manusia. 


\section{DAFTAR PUSTAKA}

Baker, David, L. Mari Mengenap Perjanjian Lama, Jakarta: BPK Gunung Mulia, 2011.

Baturi, Sani, Ernest dan Freda Maxwell. Melihat Ke Dalam Perjanjian Lama, Jakarta: kalam Hidup, 1998.

Boyd, Frank M. Kitab Nabi-Nabi Kecil, Malang: Gandum Mas, 2011.

Ensiklopedia Alkitab

Kramer, A. Th. Tafsiran Alkitab Kitab Yunus, Jakarta: BPK Gunung Mulia, 1998. 
84| Jurnal Teologi SANCTUM DOMINE 